\title{
Stature Prediction from Anthropometry of Extremities among Jordanians
}

\author{
Amal A Mashali ${ }^{*}$, Omar El taweel ${ }^{2}$ and Elerian Ekladious ${ }^{3}$ \\ ${ }^{1}$ Professor of Forensic Medicine \& Clinical Toxicology, Faculty of Medicine, Alexandria University, Egypt \\ ${ }^{2}$ Student, Mutah University, Resident at Princess Basma Teaching Hospital, Irbid, Jordan \\ ${ }^{3}$ Professor of Anatomy, Faculty of Medicine, Ein Shams University, Egypt
}

${ }^{*}$ Corresponding author: Amal A Mashali, Professor of Forensic Medicine \& Clinical Toxicology, Faculty of Medicine, Alexandria University, Egypt, E-mail: amalmashali1@gmail.com

Citation: Amal A Mashali, Omar El taweel, Elerian Ekladious (2017) Stature Prediction from Anthropometry of Extremities among Jordanians. J Forensic Sci Criminol 5(2): 202

Received Date: December 26, 2016 Accepted Date: April 04, 2017 Published Date: April 06, 2017

\begin{abstract}
Stature of an individual has an important role in identification, which is often required in medico-legal practice. The estimation of stature is an important step in the identification of dismembered remains or when only a part of a skeleton is only available as in major disasters or with mutilation. There is no published data on anthropological data among Jordanian population. The present study was designed in order to find out relationship of stature to some anthropometric measures among a sample of Jordanian population and to determine the most accurate and reliable one in predicting the stature of an individual.

A cross sectional study was conducted on 314 adult healthy volunteers, free of bone diseases, nutritional diseases and abnormalities in the extremities after taking their consent. Students of Faculty of Medicine, Mutah University helped in collecting the data. The anthropometric measurements (anatomically defined) were stature, humerus length, hand length and breadth, foot length and breadth, foot index and knee height on both right and left sides of the body. The measurements were typical on both sides of the bodies of the studied sample. All the anthropometric data showed significant relation with age except the knee height. There was a significant difference between male and female measurements. There was a significant positive correlation between the different measures and the stature of the individuals. The most sensitive measure for prediction of a stature from the measurements in the entire studied sample and in males was found to be the humerus length, while in females it was the knee height. Three sets of equations, each of three equations, were developed for estimation of stature from the different measurements, after excluding all the nonsignificant parameters with a high rate of accuracy. The equations were verified by using the same partcipants' data with a high rate of accuracy. These formulae are applicable to the Jordanian population only, due to inherent variations in these dimensions which may be attributed to biological and environmental factors.
\end{abstract}

Keywords: Foot index, Foot length, Hand length, Humerus length, Stature

\section{Introduction}

Forensic anthropology is the specialized sub-discipline of physical anthropology that applies the techniques of osteology and skeletal identification to problems of legal concern [1]. Ascertaining major biological characteristics such as age, sex, race/ ethnicity and stature are often the first pieces of data that help focus the investigation on specific group characteristics. When remains are complete, determining sex, race/ethnicity and stature can be done without difficulty [2].

Stature provides insight into various features of a population including nutrition, health and genetics. An experienced physical anthropologist can estimate the height of an individual if complete long bones are present. This is done by accurately measuring the long bones and comparing these measurements to charts based on regression formulae that have been developed after many measurements of skeletal remains [1]. The best skeletal elements to use are the long bones of the arms and legs. One of the pioneers in the study of stature estimation was Dr. Mildred Trotter in World War II [3]. Different formulas have been developed using long bones for reconstruction of stature from skeletal / dismembered remains as Steele's formula and Bayesian approaches [2,4].

With the increasing frequency of mass disasters, homicides, air plane crashes, train and road accidents etc., there is always need for such studies which help in identifying the deceased from fragmentary and dismembered human remains. Many authors have successfully tried to estimate stature from percutaneous body measurements [5-10]. Other studies correlated foot dimensions with stature and with sex differences [11,12]. Stature was estimated from various measurements of the foot like foot length and breadth based on statistical equations and formulae [13-17]. Many studies were successfully performed on this topic despite a wide range of ethnics and races through the populations. Most of the studies about stature estimation are concentrated on upper and lower extremities $[18,19]$. 
In Jordan, there were no published studies regarding anthropometric measurements. Therefore, the present study was designed in order to find out relationship of stature to some anthropometric measures among a sample of Jordanian population and to determine the most accurate and reliable one in predicting the stature of an individual.

\section{Materials and Methods}

Approval of the ethics committee of Faculty of Medicine, Mutah University was obtained after reviewing the proposal.

Informed consent was obtained from every subject with explanation of the purpose and nature of the study.

The study is a cross-sectional one on a sample of 314 normal healthy volunteering adults, Jordanians, above age of 18 up to 45 .

Exclusion criteria were bone disease, nutritional or developmental disorders and orthopedic deformities.

Demographic data were obtained including the name of the family, occupation and the governance of residence.

Anthropometric measures were recorded in centimeters, using Stadiometer and Sliding Calipers, according to the techniques described by Vallois [20]. The anthropometric measurements were hand length, hand breadth, foot length, foot breadth, humerus length and knee height were taken independently on the left and right side of each individual. The dimensions of hand and foot (Figure 1) were measured following the International Biological Program Protocol $[21,22]$. The measurements were done by the group of students assisting in the research and redone by researchers. The mean values were taken in the study.

a) Stature: Height-vertex (stature): the vertical distance between the point vertex and the floor. Vertex is the highest point on the head is held in (Frankfurt Horizontal) plane. The subject was made to stand in a standing posture and measurement was taken without any wear on head and foot.

b) Hand length: The distance between the points inter-stylion and the tip of the third finger. Inter-stylion: is the middle point of the line connecting the point stylion radial (the most distal point on the styloid process of radius) and stylion ulnare (the most distal point on the styloid process of ulna) (right and left).

c) Hand breadth: The distance between the most prominent point, outside of the lower epiphyses of the 2nd metacarpal (metacarpal radiale) to the most prominent inside point of the lower epiphyses (metacarpal ulnare) of the 5th metacarpal (right and left).

d) Foot length: The straight distance between the most backward point on the heel of the foot (pternion) and the most forward placed point on the longest toe of the foot (acropodian) when the foot is fully stretched (right and left).

e) Foot breadth: The distance between the points of the anterior epiphyses (distal) of the 1st metatarsal, the most prominent of the inner side of the foot (metatarsal-tibiale), and the joint of the anterior epiphyses of the 5th metatarsal, the most prominent of the outer side (metatarsal-fibulare) (right and left).

f) Foot index: Was calculated individually for both feet in males and females by using the formula: Foot index $=($ foot breadth/foot length) X 100.

g) Humerus length : From just below the most prominent point of the shoulder to the midpoint between the lateral and medial epicondyles (right and left).

h) Knee height: From the midpoint between the 2 condyles of femur to the floor (right and left).

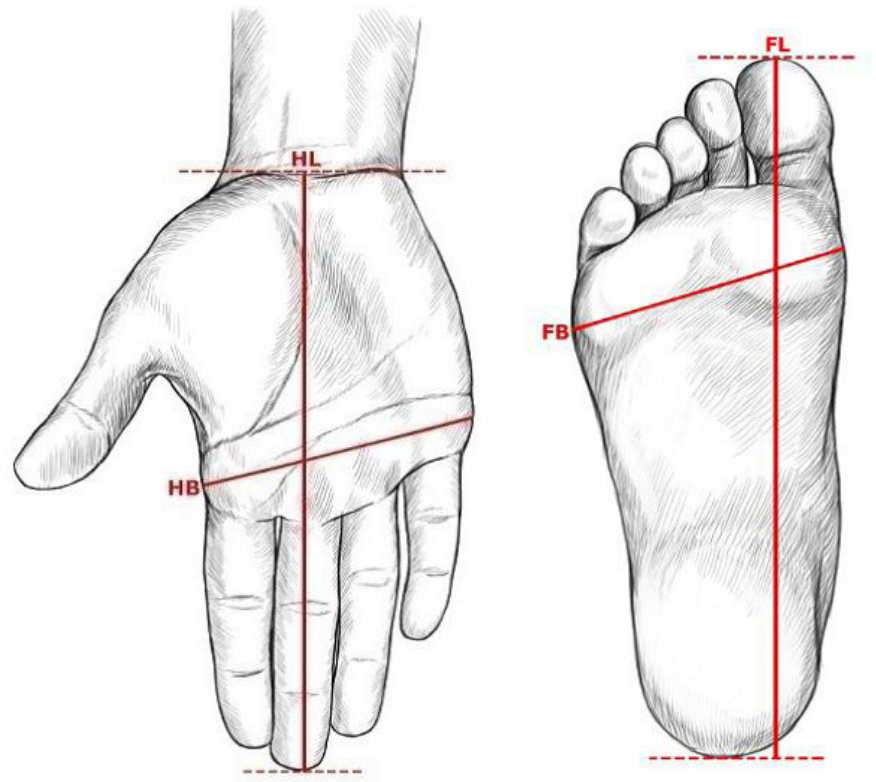

Figure 1: Diagram showing the measurements of the length and breadth of hand and the length and breadth of foot 


\section{Statistical analysis}

Data were subjected to statistical analysis using Statistical Package for Social Sciences (SPSS) version 16. Results were expressed as arithmetic mean and standard deviations. Student t-test and F-test were used to establish any significant differences. Linear regression analysis was undertaken to derive predictive equations for estimation of stature using the different parameters, except the non-significant parameters. The regression formulae were calculated for various combinations to reach the best estimate possible. The level of significance was set at $\mathrm{p} \leq 0.05$.

\section{Results}

The study included 314 healthy Jordanian adults, 144 females and 170 males. Their ages ranged between 18 and 45 years.

Table 1 show that the stature ranged between 144 and $190 \mathrm{~cm}$, with a mean of $167.74 \pm 9.82 \mathrm{~cm}$.

\begin{tabular}{|c|c|c|}
\hline Stature & Number & Percent \\
\hline $144-150$ & 9 & 2.9 \\
\hline $151-160$ & 76 & 24.2 \\
\hline $161-170$ & 99 & 31.5 \\
\hline $171-180$ & 101 & 32.2 \\
\hline $181+$ & 29 & 9.2 \\
\hline Total & 314 & 100.0 \\
\hline Range & \multicolumn{2}{|c|}{$144-190$} \\
\hline Mean & \multicolumn{2}{|c|}{167.74} \\
\hline S.D. & \multicolumn{2}{|c|}{9.82} \\
\hline Median & \multicolumn{2}{|c|}{171.0} \\
\hline
\end{tabular}

Table 1: Distribution of the studied sample regarding their stature $(\mathrm{n}=314)$

Table 2 compared the means of the bilateral measurements of the studied sample. There was no significant statistical difference for all parameters on the left and right sides. However, the right side presented higher mean values in most measurements.

\begin{tabular}{|c|c|c|c|c|}
\hline & Mean & $\begin{array}{c}\text { Std. } \\
\text { Deviation }\end{array}$ & $\begin{array}{c}\text { Std. Error } \\
\text { Mean }\end{array}$ & $\mathbf{p}$ \\
\hline Knee height R & 33.16 & 3.182 & .180 & \multirow{2}{*}{0.136} \\
\hline Knee height L & 33.12 & 3.173 & .179 & \\
\hline Foot breadth R & 8.97 & .970 & .055 & \multirow{2}{*}{0.116} \\
\hline Foot breadth L & 8.91 & .942 & .053 & \\
\hline Foot length $\mathrm{R}$ & 18.856 & 1.6729 & .0944 & \multirow{2}{*}{0.419} \\
\hline Foot length L & 18.867 & 1.6657 & .0940 & \\
\hline Hand length $R$ & 25.36 & 2.209 & .125 & \multirow{2}{*}{0.376} \\
\hline Hand length $L$ & 25.30 & 2.403 & .136 & \\
\hline Hand breadth $R$ & 10.79 & 1.351 & .076 & \multirow{2}{*}{0.335} \\
\hline Hand breadth L & 10.74 & 1.550 & .087 & \\
\hline $\begin{array}{l}\text { Length of } \\
\text { humerus } R\end{array}$ & 46.067 & 5.6143 & .3168 & \multirow{2}{*}{0.404} \\
\hline $\begin{array}{r}\text { Length of } \\
\text { humerus L }\end{array}$ & 46.151 & 5.1903 & .2929 & \\
\hline Foot index $R$ & 47.706 & 5.0808 & .2867 & \multirow{2}{*}{0.102} \\
\hline Foot index $\mathrm{L}$ & 47.382 & 4.9758 & .2808 & \\
\hline
\end{tabular}

Table 2: Comparison between right and left measurements of different parts in the studied sample

Table 3 shows descriptive statistics for all measurements with age. There was a statistically significant relation for all parameters except for knee height, where $\mathrm{F}=2.491, \mathrm{P}=0.060$.

Table 4 shows that stature of males ranged between 154 and $190 \mathrm{~cm}$ with a mean of $174.68 \pm 6.624$ and that of females ranged between 148 and $182 \mathrm{~cm}$ with a mean of $159.55 \pm 5.893$. This depict a statistically significant difference between statures of males and females, where $\mathrm{t}=449.792$ and $\mathrm{P}=0.0001$.

All measurements in both sexes showed that males were having greater mean values of all measurements with a significant statistical difference, except for foot index where $\mathrm{t}=1.380$ and $\mathrm{P}=0.241$. 


\begin{tabular}{|c|c|c|c|c|c|c|c|c|}
\hline & & $\mathbf{N}$ & Min. & Max. & Mean & S.D. & $\mathbf{F}$ & $\mathbf{p}$ \\
\hline \multirow{4}{*}{ Stature } & $<20$ & 25 & 148 & 178 & 159.7 & 8.1 & 11.194 & $0.0001^{* *}$ \\
\hline & $20-30$ & 233 & 148 & 190 & 169.4 & 9.7 & & \\
\hline & $30-40$ & 36 & 148 & 184 & 165.6 & 9.2 & & \\
\hline & $40+$ & 20 & 152 & 176 & 162.5 & 7.4 & & \\
\hline \multirow{4}{*}{ Knee height } & $<20$ & 25 & 27 & 40 & 31.9 & 2.9 & 2.491 & 0.060 \\
\hline & $20-30$ & 233 & 27 & 42 & 33.1 & 3.2 & & \\
\hline & $30-40$ & 36 & 29 & 44 & 34.0 & 3.1 & & \\
\hline & $40+$ & 20 & 27 & 40 & 33.8 & 3.3 & & \\
\hline \multirow{4}{*}{$\begin{array}{c}\text { Foot } \\
\text { breadth }\end{array}$} & $<20$ & 25 & 7 & 10 & 8.2 & 0.7 & 7.404 & $0.0001^{* *}$ \\
\hline & $20-30$ & 233 & 7 & 12 & 9.0 & 0.9 & & \\
\hline & $30-40$ & 36 & 7 & 11 & 9.2 & 1.0 & & \\
\hline & $40+$ & 20 & 7 & 12 & 9.2 & 1.2 & & \\
\hline \multirow{4}{*}{ Foot length } & $<20$ & 25 & 14.0 & 21.0 & 17.6 & 1.6 & 6.057 & $0.001^{\star}$ \\
\hline & $20-30$ & 233 & 15.3 & 23.0 & 19.0 & 1.5 & & \\
\hline & $30-40$ & 36 & 16.5 & 22.2 & 19.2 & 1.5 & & \\
\hline & $40+$ & 20 & 7.5 & 22.0 & 18.5 & 3.1 & & \\
\hline \multirow{4}{*}{$\begin{array}{l}\text { Hand } \\
\text { length }\end{array}$} & $<20$ & 25 & 20 & 28 & 23.8 & 1.8 & 5.008 & $0.002^{*}$ \\
\hline & $20-30$ & 233 & 16 & 32 & 25.5 & 2.2 & & \\
\hline & $30-40$ & 36 & 20 & 31 & 25.6 & 2.2 & & \\
\hline & $40+$ & 20 & 22 & 30 & 24.8 & 2.2 & & \\
\hline \multirow{4}{*}{$\begin{array}{l}\text { Hand } \\
\text { breadth }\end{array}$} & $<20$ & 25 & 7 & 12 & 9.7 & 1.4 & 6.329 & $0.0001^{* *}$ \\
\hline & $20-30$ & 233 & 6 & 15 & 10.9 & 1.3 & & \\
\hline & $30-40$ & 36 & 8 & 14 & 10.8 & 1.5 & & \\
\hline & $40+$ & 20 & 8 & 16 & 11.1 & 2.0 & & \\
\hline \multirow{4}{*}{$\begin{array}{l}\text { Length of } \\
\text { humerus }\end{array}$} & $<20$ & 25 & 32.0 & 55.0 & 42.9 & 5.5 & 3.626 & $0.013^{*}$ \\
\hline & $20-30$ & 233 & 24.5 & 56.0 & 46.5 & 5.3 & & \\
\hline & $30-40$ & 36 & 33.0 & 53.0 & 45.8 & 4.5 & & \\
\hline & $40+$ & 20 & 38.0 & 60.0 & 46.4 & 6.2 & & \\
\hline \multirow{4}{*}{ Foot index } & $<20$ & 25 & 39.5 & 51.6 & 46.4 & 3.1 & 5.314 & $0.001^{\star *}$ \\
\hline & $20-30$ & 233 & 38.1 & 58.6 & 47.3 & 3.5 & & \\
\hline & $30-40$ & 36 & 34.6 & 55.6 & 48.0 & 4.2 & & \\
\hline & $40+$ & 20 & 41.2 & 106.7 & 51.5 & 13.9 & & \\
\hline
\end{tabular}

* Significant statistically

Table 3: Relation between age and different measurements (mean value of right and left side)

\begin{tabular}{|c|c|c|c|c|c|c|c|c|}
\hline & & $\mathbf{N}$ & Min. & Max. & Mean & S.D. & $t$-test & Sig. \\
\hline \multirow{2}{*}{ Stature } & Males & 170 & 154 & 190 & 174.68 & 6.624 & 449.792 & $.0001^{* *}$ \\
\hline & Females & 144 & 148 & 182 & 159.55 & 5.893 & & \\
\hline \multirow{2}{*}{ Knee height } & Males & 170 & 28 & 42 & 33.67 & 3.125 & 10.825 & $.001^{\star *}$ \\
\hline & Females & 144 & 27 & 44 & 32.51 & 3.115 & & \\
\hline \multirow{2}{*}{$\begin{array}{c}\text { Foot } \\
\text { breadth }\end{array}$} & Males & 170 & 8 & 12 & 9.38 & 0.775 & 109.974 & $.0001^{\star *}$ \\
\hline & Females & 144 & 7 & 12 & 8.41 & 0.862 & & \\
\hline \multirow{2}{*}{ Foot length } & Males & 170 & 16.0 & 23.0 & 19.634 & 1.2240 & 106.916 & $.0001^{\star *}$ \\
\hline & Females & 144 & 7.5 & 21.9 & 17.949 & 1.6581 & & \\
\hline \multirow{2}{*}{$\begin{array}{l}\text { Hand } \\
\text { length }\end{array}$} & Males & 170 & 16 & 32 & 26.49 & 1.821 & 148.268 & $.0001^{\star *}$ \\
\hline & Females & 144 & 20 & 31 & 23.97 & 1.840 & & \\
\hline \multirow{2}{*}{$\begin{array}{c}\text { Hand } \\
\text { breadth }\end{array}$} & Males & 170 & 6 & 14 & 11.05 & 1.207 & 16.929 & $.0001^{\star *}$ \\
\hline & Females & 144 & 6 & 16 & 10.42 & 1.515 & & \\
\hline \multirow{2}{*}{$\begin{array}{l}\text { Length of } \\
\text { humerus }\end{array}$} & Males & 170 & 38.0 & 58.0 & 49.284 & 3.6056 & 225.825 & $.0001^{* *}$ \\
\hline & Females & 144 & 24.5 & 60.0 & 42.361 & 4.5535 & & \\
\hline
\end{tabular}




\begin{tabular}{|c|c|c|c|c|c|c|c|c|}
\hline & & N & Min. & Max. & Mean & S.D. & $t$-test & Sig. \\
\hline \multirow{2}{*}{ Foot index } & Males & 170 & 38.1 & 56.2 & 47.849 & 3.4767 & 1.380 & .241 \\
\cline { 2 - 10 } & Females & 144 & 34.6 & 106.7 & 47.189 & 6.2839 & & \\
\hline
\end{tabular}

* Significant statistically

Table 4: Relation between sex and different measurements (mean value of right and left side)

Table 5 illustrates the correlation between stature and the mean of different measurements (left and right, as there was no difference between both sides) in males and females. There was a significant positive correlation between all measures and stature in females except for foot index, where $r=0.037$ and -0.06 respectively. In males there was a significant positive correlation between all variables measured except the foot breadth $(r=0.086, \mathrm{P}=0.263)$.

\begin{tabular}{|c|c|c|c|c|c|c|}
\hline \multirow{2}{*}{ Stature \# } & \multicolumn{2}{|c|}{ Male } & \multicolumn{2}{c|}{ Female } & \multicolumn{2}{c|}{ Total } \\
\cline { 2 - 7 } & $\mathbf{r}$ & $\mathbf{p}$ & $\mathbf{r}$ & $\mathbf{p}$ & $\mathbf{r}$ & $\mathbf{p}$ \\
\hline Knee height & 0.385 & $0.001^{* *}$ & $\underline{0.586}$ & $0.001^{* *}$ & 0.436 & $0.001^{* *}$ \\
\hline $\begin{array}{c}\text { Foot } \\
\text { breadth }\end{array}$ & 0.086 & 0.263 & 0.476 & $0.001^{* *}$ & 0.537 & $0.001^{* *}$ \\
\hline Foot length & 0.425 & $0.001^{* *}$ & 0.539 & $0.001^{* *}$ & 0.649 & $0.001^{* *}$ \\
\hline $\begin{array}{c}\text { Hand } \\
\text { length }\end{array}$ & 0.482 & $0.001^{* *}$ & 0.575 & $0.001^{* *}$ & 0.711 & $0.001^{* *}$ \\
\hline $\begin{array}{c}\text { Hand } \\
\text { breadth }\end{array}$ & 0.202 & $0.008^{*}$ & 0.375 & $0.001^{* *}$ & 0.350 & $0.001^{* *}$ \\
\hline $\begin{array}{c}\text { Length of } \\
\text { humerus }\end{array}$ & $\underline{0.504}$ & $0.001^{* *}$ & 0.497 & $0.001^{* *}$ & $\underline{0.738}$ & $0.001^{* *}$ \\
\hline Foot index & -0.264 & $0.001^{*}$ & -0.06 & 0.477 & 0.037 & 0.513 \\
\hline
\end{tabular}

${ }^{*}$ Significant positive correlation

Table 5: Correlation between different measurements (as mean of right and left)

This correlation was important to predict the most significant variable which has effect on the equation in stature calculation.

The best measurement for predicting stature for all the sample studied and for males was the length of humerus, where $\mathrm{r}=0.738$ and 0.504 respectively. In females the best measurement for predicting stature was the knee height $(\mathrm{r}=0.586)$.

Three sets of equations, each of three equations, were developed for estimation of stature from the different measurements, after excluding all the nonsignificant parameters, as shown in table 6.

\begin{tabular}{|c|c|c|c|}
\hline Subjects & Parameters & Equation & Accuracy \\
\hline \multirow{3}{*}{$\begin{array}{l}\text { Whole } \\
\text { subjects } \\
(\mathrm{n}=314)\end{array}$} & $\begin{array}{l}\text { Using all measurements (except } \\
\text { nonsignificant ones) }\end{array}$ & $\begin{array}{c}\text { Stature }=69.42+(0.142 \times \text { knee height })+(0.521 \times \text { Foot } \\
\text { breadth })+(1.452 \times \text { foot length })+(1.239 \times \text { hand length })- \\
(0.474 \times \text { hand breadth })+(0.764 \times \text { length of humerus })\end{array}$ & $87.1 \%$ \\
\hline & $\begin{array}{l}\text { Using upper limb measurements } \\
\text { (except nonsignificant ones) }\end{array}$ & $\begin{array}{c}\text { Stature }=83.89+(1.686 \times \text { hand length })+(0.072 \times \text { hand } \\
\text { breadth })+(0.875 \times \text { length of humerus })\end{array}$ & $845 \%$ \\
\hline & $\begin{array}{l}\text { Using lower limb measurements } \\
\text { (except nonsignificant ones) }\end{array}$ & $\begin{array}{c}\text { Stature }=88.433+(0.251 \times \text { knee height })+(1.806 \times \text { foot } \\
\text { breadth })+(2.908 \times \text { foot length })\end{array}$ & $85.0 \%$ \\
\hline \multirow{3}{*}{$\begin{array}{l}\text { For males } \\
(\mathbf{n}=170)\end{array}$} & $\begin{array}{l}\text { Using all measurements } \\
\text { (except nonsignificant ones) }\end{array}$ & $\begin{array}{c}\text { Stature }=107.031+(0.403 \times \text { knee height })+(1.027 x \text { foot } \\
\text { length })+(0.855 x \text { hand length })-(0.417 x \text { hand breadth })+ \\
(0.609 x \text { length of humerus })-(0.296 x \text { foot index })\end{array}$ & $83.8 \%$ \\
\hline & $\begin{array}{l}\text { Using upper limb measurements } \\
\text { (except nonsignificant ones) }\end{array}$ & $\begin{array}{c}\text { Stature }=134.865+(0.949 \mathrm{x} \text { hand length })+(0.339 \mathrm{x} \text { hand } \\
\text { breadth })+(0.646 \mathrm{x} \text { length of humerus })-(0.437 \mathrm{x} \text { foot } \\
\text { index })\end{array}$ & $80.0 \%$ \\
\hline & $\begin{array}{l}\text { Using lower limb measurements } \\
\text { (except nonsignificant ones) }\end{array}$ & $\begin{array}{c}\text { Stature }=126.437+(0.464 \times \text { knee height })+(1.661 \times \text { foot } \\
\text { length })\end{array}$ & $79.5 \%$ \\
\hline \multirow{3}{*}{$\begin{array}{l}\text { For females } \\
\qquad(\mathrm{n}=144)\end{array}$} & $\begin{array}{l}\text { Using all measurements } \\
\text { (except nonsignificant ones) }\end{array}$ & $\begin{array}{c}\text { Stature }=102.935+(0.493 \times \text { knee height })-(0.159 \times \text { Foot } \\
\text { breadth })+(0.822 \times \text { foot length })+(0.643 \times \text { hand length })+ \\
(0.168 \times \text { hand breadth })+(0.227 \times \text { length of humerus })\end{array}$ & $83.0 \%$ \\
\hline & $\begin{array}{l}\text { Using upper limb measurements } \\
\text { (except nonsignificant ones) }\end{array}$ & $\begin{aligned} \text { Stature }= & 111.518+(1.171 \times \text { hand length })+(0.430 \times \text { hand } \\
& \text { breadth })+(0.366 \times \text { length of humerus })\end{aligned}$ & $78.1 \%$ \\
\hline & $\begin{array}{l}\text { Using lower limb measurements } \\
\text { (except nonsignificant ones) }\end{array}$ & $\begin{array}{c}\text { Stature }=112.640+(0.733 \times \text { knee height })+(0.423 \times \text { foot } \\
\text { breadth })+(1.088 \times \text { foot length })\end{array}$ & $79.0 \%$ \\
\hline
\end{tabular}

Table 6: The three sets of linear regression equations developed to estimate the stature from the measurements of the studied sample 
The equations were verified by using the same partcipants' data with a high rate of accuracy.

Accuracy of the linear equations for estimating stature from measurements of all cases studied and males of studied sample was highest using all data followed by using measurements of upper limbs then using those of upper limbs. Accuracy of the linear equation for estimating stature from measurements of all females of studied sample was higher using measurements of all data followed by using those of lower limbs then those of upper limb.

\section{Discussion}

In medico-legal autopsies, establishing personal identity of the victims is often required. Estimation of stature from extremities and their parts plays an important role in identifying the dead in forensic examinations [14].

The study included 314 healthy Jordanian adults, 144 females and 170 males. The stature ranged between 144 and $190 \mathrm{~cm}$, with a mean of $167,74 \pm 9.82 \mathrm{~cm}$.

The present study did not show any significant statistical difference for all parameters on the left and right sides. However the right side presented higher mean values in most measurements. Similar results were obtained by different researches [14].

A statistically significant relation was found between age and stature of the studied sample. The stature obtained by different researchers such as Duyar., et al. Nath., et al. and Narde and Dongre varies slightly. This might be due to geographical variations, which play an important role in human development and growth [23-25].

In the current study, males were having greater mean values of all measurements with a significant statistical difference, except for foot index. These results are in accordance with many other works in different researches. These statistically significant differences may be attributed to the early maturity of girls than boys. These were in accordance with results of Ozaslan., et al. and Krishan and Sharma [6,14].Hormonal, genetic and environmental factors are effective in occurring of physical characteristics between sexes; Age of puberty being 2years later in males as compared with females giving them extra time for growth [26,27].

In the present study there was a significant positive correlation between all measures and stature in females except for foot index. In males there was a significant positive correlation between all variables measured except the foot breadth. This correlation was important to predict the most significant variable which has effect on the equation in stature calculation. These results are in accordance with Krishan and Sharma and Ozaslan., et al. [6,14].

The study revealed that best measurement for predicting stature for the sample studied and for males was the length of humerus, while in females it was the knee height. Ozaslan., et al. found that the best correlation coefficient was determined in males for stature estimation as follows; in hand dimensions for hand length and in foot dimensions for foot length. Also in females; hand length presented the best correlation between hand dimensions and stature [6].

Krishan and Sharmain their study found that the dimensions of hands and feet can successfully be used for estimation of stature and recommended to use them by law enforcement agencies and forensic scientists. The only precaution which must be taken into consideration is that these formulae were applicable to the population from which the data have been collected due to inherent population variations in these dimensions which may be attributed to genetic and environmental factors like climate and nutrition [14].

Three sets of equations, each of three equations, were developed for estimation of stature from the different measurements, after excluding all the nonsignificant parameters. The equations were verified by using the same partcipants' data with a high rate of accuracy.

Similar to our results, Sanli., et al. also stated that the multiple linear regression models is best fitted than simple linear regression model for estimating height from foot length and hand length [15].

Qamra., et al. explored from his study that foot length appeared to be a suitable measurement than foot breadth for stature estimation [28].

Giles., et al. presented linear regressions for determining height from foot length for males and females [29].

\section{Conclusion}

It is concluded that males have greater mean value of stature as compared to that of females.

The results of the present study show that the dimensions of hands and feet can successfully be used for estimation of stature by law enforcement agencies and forensic scientists. These formulae are applicable to the Jordanian population only, due to inherent variations in these dimensions which may be attributed to biological and environmental factors. These equations may be helpful to obtain approximate stature of an individual when there is difficulty in obtaining direct measurement such as in fragmented remains of body. 


\section{Acknowledgement}

The authors are grateful to the students of fourth and fifth year Medicine, Faculty of Medicine, Mutah University, Jordan, in 2011 for their assistance in the study in many data collection and tabulation.

\section{References}

1. Ellis Kerley (1978) In: Warren MW, Walsh-Haney HA, Freas L E (2008) The Forensic Anthropology laboratory, CRC Press: Taylor \& Francis: London, New York 5-18.

2. Pickering R, Bachman D (2009) The use of Forensic Anthropology (2nd Ed), CRC Press, Taylor \& Francis, London, New York 7-17.

3. Ellis Kerley (1978) In: Warren M W , Walsh-Haney H A , Freas L E. The Forensic Anthropology laboratory (2008) CRC Press, Taylor \& Francis, London, New York 5-18.

4. Gelman A, Carlin JB, Stern HS, Rubin DB (2004) Bayesian Data analysis. Chapman \& Hall, CRC Press, Boca Raton, Fl 319-329.

5. Abdel-Malek AK, Ahmed AM, Sharkawi SAA, Hamid NMA (1990) Prediction of stature from hand measurements. Forensic Sci Int 46: 181-7.

6. Ozaslan A, Iscan MY, Ozaslan I, Tugcu H, Koc S (2003) Estimation of stature from body parts. Forensic Sci Int 132: 40-5.

7. Kumar A, Srivastava AK, Verma AK (2010) Estimation of Stature by Percutaneous Measurements of Distal Half of Upper Limb (Forearm \& Hand). J Indian Acad Forensic Med 32: 325-8.

8. Jain P, Kaur S, Nath S (1996) Reconstruction of stature from hand and foot dimensionsamong male Brahmins of Kumaon (India). J Ind Acad Forensic Sci 35: $22-9$.

9. Sen J, Ghosh S (2008) Estimation of stature from foot length and foot breadth among the Rajbansh: an indigenous population of North Bengal. Forensic Sci Int 181: 1-6.

10. Zeybek G, Ergur I, Demiroglu Z (2008) Stature and gender estimation using foot measurements. Forensic Sci Int 181: 1-5.

11. Ozden H, Balci Y, Demirustu C, Turgut A, Ertugrul M (2005) Stature and sex estimate using foot and shoe dimensions. Forensic Sci Int 147: 181-4.

12. Sigh JP, Meena MC, Rani Y, Sharma GK (2013) Stature Estimation from the Dimensions of Foot in females. Antrocom Online Journal of Anthropology 9: 237-41.

13. Agnihotri AK, Purwar B, Googoolybe K, Agnihotri S, Jeebun N (2007) Estimation of stature by foot length. J Forensic Leg Med 14: $279-83$.

14. Krishan K, Sharma A (2007) Estimation of stature from dimensions of hands and feet in North Indian population. J Forensic Leg Med 14: 327-32.

15. Sanli SG, Kizilkanat ED, Boyan N, Ozsahin ET, Bozkir MG, et al. (2005) Stature estimation based on hand length and foot length. Clin Anat 18: 589-96.

16. Saxena SK (1984) A study of correlations and estimation of stature from hand length, hand breadth and sole length. Anthropol Anz 42: 271-6.

17. Quamara SR, Jit I, Deodhar SD (1980) A model for construction of height from foot measurements in an adult population of North west India. Ind J Med Res 71: $77-83$

18. Ozaslan A, Karadayi B, Ahsen Kaya A, Afsin H (2012) Predictive role of hand and foot dimensions in stature estimation. Rom J Leg Med 20: $41-46$.

19. Celbis O, Agritmis H (2006) Estimation of stature and determination of sex from radial and ulnar bone lengths in a Turkish corpse sample. Forensic Sci. Int 158: 135-9.

20. Vallois HV (1965) Anthropometric techniques. Curr Anthropol 6: 127-44.

21. Weiner JS, Lourie JA (1969) Human Biology: A guide to field methods, Blackwell Scientific Publications, Oxford.

22. Olivier G (1969) Practical Anthropology, C.C. Thomas, Springfield, IL.

23. Duyar I, Pelin C, Zagyapan R (2006) A new method of stature estimation for forensic anthropological application. Anthrop Sci 114: 23-27.

24. Nath S, Jain P (2005) Use of lower limb measurements in estimation of the stature. Forensic-Anthropology Science and Medicine. (1st Ed) Delhi: Kamla-Raj Enterprises: $37-43$.

25. Narde AL, Dongre AP (2013) Body Height Estimation Based on Foot Length and Foot Breadth. J Indian Acad Forensic Med 35.

26. Hasegawa I, Uenishi K, Fukumaga T, Kimura R, Osawa M (2009) Stature estimation formulae from radiologically determined limb bone length in a modern Japanese population. Leg Med 11: 260-66.

27. Malina RM, Little BB, Stern MP, Gaskill SP, Hazuda HP (1983) Ethnic and social class differences in selected anthropometric characteristics of Mexican American and Anglu adults: The San Antonio heart study. Hum Biol 55: 867-83.

28. Qomara SR, Jit I, Deodhar SD (1980) A model of reconstruction of height from foot measurement in an adult population of Northwest India. Indian J Med Res 71: 77-83

29. Giles E, Vallendigham PH (1992) Height estimation from foot and shoeprint length. J Forensic Sci May 36: 1134-1151. 


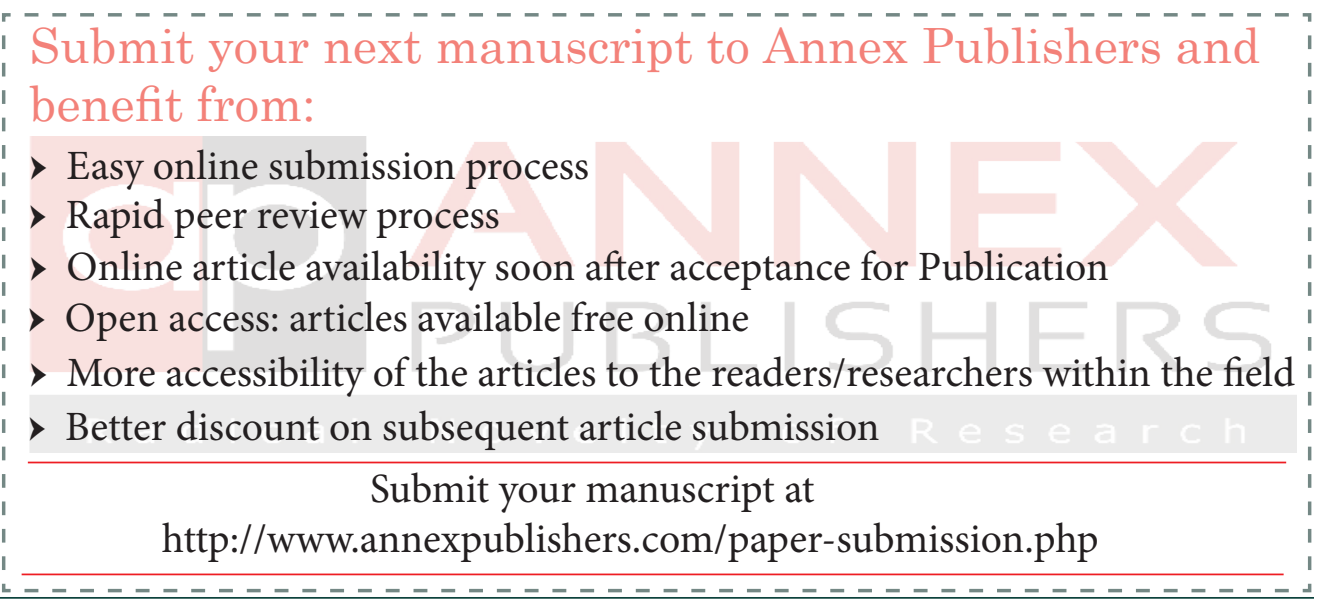

